\title{
CORRELATION BETWEEN CLINICAL PROFILE, CD 4 COUNT AND TOTAL LYMPHOCYTE COUNT IN HIV INFECTED PERSONS
}

Keshava H.K ${ }^{1}$, Manjunath $\mathrm{R}^{2}$

\section{HOW TO CITE THIS ARTICLE:}

Keshava H.K, Manjunath R. "Correlation between Clinical Profile, CD 4 Count and Total Lymphocyte Count in HIV infected persons". Journal of Evolution of Medical and Dental Sciences 2014; Vol. 3, Issue 05, February 03; Page: 1264-1275, DOI: $10.14260 /$ jemds/2014/1979

ABSTRACT: BACKGROUND \& OBJECTIVES: HIV infection can be monitored by laboratory and clinical markers of disease progression. In the absence of CD 4 count, the use of Total Lymphocyte Count has been advocated to predict CD 4 count and to stage HIV disease. This study was undertaken to show whether the TLC accurately predicts a low CD 4 count in HIV infected persons and its clinical correlation. METHODOLOGY: The data for the study was collected from HIV positive inpatients and outpatients of KIMS Hospital, Bangalore from March 2004 to March 2006. A total 50 patients were subjected to clinical examination and relevant investigations including CD 4 Count and TLC. RESULTS: In our study, males (39), outnumbered females (11). The major risk factor for HIV infection in these patients was unprotected, multiple sexual contacts. Fever, Anorexia, Weight loss, Lethargy, Cough, Diarrhea and Mouth ulcers were the common presenting symptoms. Tuberculosis, Chronic diarrhea, Oropharyngeal candidiasis were the most common opportunistic infections. Majority of the patients had CD 4 Count less than 350 cells/ $\mu$ l and were symptomatic. The Total Lymphocyte Counts of 1750 cells/ $\mu$ l and 2450 cells/ $\mu \mathrm{l}$ correlated to CD 4 counts of 200 cells/ $\mu \mathrm{l}$ and 350 cells/ $\mu$ l respectively. INTERPRETATION \& CONCLUSION: There was a highly significant correlation between CD 4 Count and Total Lymphocyte Count. TLC can be used as an effective laboratory tool to monitor disease progression in HIV infected persons where CD 4 is not available and in resource poor countries.

KEYWORDS: TLC, CD 4 Count, HIV infection, Correlation.

INTRODUCTION: The Ministry of Health and Family Welfare and National AIDS Control Organization has estimated that the current number of people living with HIV infection in India is more than 5.13 million ${ }^{1}$. It is estimated that $90 \%$ of HIV infected persons worldwide live in resource poor developing countries $^{2}$.The number of people living with HIV/AIDS continues to increase in several regions, most markedly in sub-Saharan Africa, with Southern Africa registering the highest prevalence. Asia and the Pacific as well as Eastern Europe and Central Asia continue to experience expanding epidemics, with the number of people living with HIV/AIDS growing year by year ${ }^{3}$.

The cost of antiretroviral therapy (ART) is dropping dramatically for low-income countries through various international initiatives. As availability of antiretroviral medications improves, it is important to develop feasible strategies for the clinical management of antiretroviral therapies in resource-limited settings ${ }^{1}$. One of the major obstacles to the administration of ART is the absence of sophisticated and expensive laboratory equipment and infrastructure required for monitoring the efficacy of therapy ${ }^{1-4}$. In industrialized nations, changes in CD 4 count and plasma viral load are used to determine the responses of the virus to antiretroviral therapy. Standard methods of CD 4 count and plasma viral load enumeration require highly trained personnel and tens of thousands of dollars of initial investment in laboratory instrumentation ${ }^{5}$. In few resource limited countries where such 
laboratory facilities exist, they are often concentrated in major cities and the assays are too expensive for the majority of patients to use for routine monitoring of ART.

Hence the WHO recommends the use of TLC to monitor the immune response to ART ${ }^{2}$. TLC is an inexpensive and widely available laboratory parameter. TLC is easily obtained from the routine complete blood count (CBC) with differential by multiplying percentage lymphocytes by leukocyte count. In India, where the average annual income is $<\$ 350$ (US), the cumulative cost of monitoring SRT becomes a significant financial challenge ${ }^{6}$.

In light of its low cost and widespread availability, TLC has already been a useful tool in lowincome countries for predicting immunosuppression and triggering opportunistic infection prophylaxis $^{7-11}$. Recent studies have also demonstrated that TLC alone and in combination with hemoglobin may be useful in determining when to initiate antiretroviral therapy ${ }^{12-14}$. However, there are fewer studies examining the change of TLC in patients on antiretroviral therapy 15 .

The purpose of this dissertation is to assess the capability and clinical utility of TLC change to serve as a surrogate marker for CD 4 count change in monitoring patients, which has important implications for resource-limited settings. We are correlating CD 4 Count to Total Lymphocyte Count, which is available in all resource limited settings as it is obtained by multiplying Total Leucocyte Count and percentage of Lymphocyte in Differential Count, to monitor disease progression in HIV infected persons.

This dissertation is also an attempt to look into the correlation between opportunistic infections and progression of the disease, which is monitored by change in CD 4 count and TLC. Since our study is being done in the resource poor set-up, the observations and conclusions can be used for monitoring progression of disease in HIV infected persons in our own set-up as well as other resource limited settings.

\section{OBJECTIVE:}

- To determine whether the Total Lymphocyte Count accurately predicts a low CD 4 count in HIV infected persons and its clinical correlation.

\section{METHODOLOGY:}

\section{SUBJECTS AND METHODS:}

Sources of data: In this study, all HIV positive patients with or without symptoms who visited KIMS Hospital as outpatients or as inpatients in the medical wards.

Place of study: The study was conducted in Kempegowda Institute of Medical Sciences and Research Centre, Bangalore.

Study Period: The study was conducted from March 2004 to March 2006.

Study Design: A Cross sectional descriptive study.

\section{Inclusion Criteria:}

- All HIV positive patients.

\section{Exclusion Criteria:}

- Cases on cytotoxic drugs.

- Cases with connective tissue disorders. 
Collection of Data: A total of 50 HIV positive patients who were admitted in KIMS Medical wards and those who visited Medical OPD were the study group.

A detailed history was obtained using a pre-tested proforma from all the patients, who were included in the study. Further, a detailed systemic examination followed by relevant investigations as mentioned in the proforma were conducted and results were noted.

METHODS: Venous samples were sent for evaluation of CD 4 count by Flow cytometry method.

Sample taken at the same time was also sent for evaluation of Total count and Differential count.

HIV infection was proved with: HIV antibody detection by ELISA method

Total lymphocyte count (TLC) was calculated by multiplying the differential count (DC) with Total leukocyte count (TC).

$$
[\mathrm{TLC}=\mathrm{TC} \times \mathrm{DC}]
$$

Sensitivity and specificity of various Total lymphocyte count cut-off were computed for CD 4 count $<200$ cells $/ \mu$ l and $<350$ cells $/ \mu$ l. We evaluated changes in Total Lymphocyte count as a diagnostic monitoring marker of benchmark changes in CD 4 count that indicates favorable response to ART.

In the patients who were symptomatic the following investigations were done wherever necessary.

Collection and Processing of Specimens: Various samples e.g. Sputum, oral swab, blood, stool, urine, cerebrospinal fluid (CSF), lymph node aspirate were collected as per symptoms and clinical presentations. All the specimens were collected under universal aseptic precautions in suitable sterile containers ${ }^{16}$.

ETHICAL CLEARANCE: The ethical clearance was obtained from the Ethical Committee of Kempegowda Institute of Medical Sciences, Bangalore.

STATISTICAL METHODS: Analysis of variance has been used to find the significance of study parameters with variations with CD4 counts.

Pearson correlation co-efficient has been used to find the correlation of CD4 counts with study parameters.

Statistical software: The Statistical software namely SPSS 11.0 and Systat 8.0 were used for the analysis of the data and Microsoft word and Excel have been used to generate graphs, tables etc.

RESULTS: Between March 2004 and March 2006, 50 HIV positive patients admitted in KIMS hospital or patients who were examined in the Medical OPD were selected to constitute the study population. 
ORIGINAL ARTICLE

\begin{tabular}{|c|c|c|c|c|c|c|}
\hline \multirow{2}{*}{ Age in years } & \multicolumn{2}{|c|}{ Male } & \multicolumn{2}{c|}{ Female } & \multicolumn{2}{c|}{ Total } \\
\cline { 2 - 7 } & No & $\%$ & No & $\%$ & No & $\%$ \\
\hline$\leq 30$ & 4 & 10.3 & 4 & 36.4 & 8 & 16.0 \\
\hline $31-40$ & 17 & 43.6 & 5 & 45.5 & 22 & 44.0 \\
\hline $41-50$ & 11 & 28.2 & 2 & 18.2 & 13 & 26.0 \\
\hline $51-60$ & 6 & 15.4 & - & - & 6 & 12.0 \\
\hline$>60$ & 1 & 2.6 & - & - & 1 & 2.0 \\
\hline Total & 39 & 100.0 & 11 & 100.0 & 50 & 100.0 \\
\hline Mean \pm SD & $41.38 \pm 10.10$ & $35.45 \pm 8.85$ & $40.08 \pm 10.07$ \\
\hline
\end{tabular}

It is observed that $22(44 \%)$ patients were in the age group of 31-40.

\begin{tabular}{|c|c|c|c|}
\hline Risk exposure & $\begin{array}{c}\text { Total } \\
(\mathbf{n = 5 0 )}\end{array}$ & $\begin{array}{c}\text { Male } \\
(\mathbf{n = 3 9 )}\end{array}$ & $\begin{array}{c}\text { Female } \\
(\mathbf{n = 1 1})\end{array}$ \\
\hline A. Sexual contacts & $48(96.0 \%)$ & $37(74.0 \%)$ & $11(22.0 \%)$ \\
\hline 1. Hetero sexual & $31(64.6 \%)$ & $27(72.9 \%)$ & $4(36.4 \%)$ \\
\hline 2. Hetero sexual +STD & $12(25.0 \%)$ & $10(27.1 \%)$ & $2(18.2 \%)$ \\
\hline 3. Homosexual +STD & & - & - \\
\hline 4. Spouse of HIV + & $5(10.4 \%)$ & - & $5(45.5 \%)$ \\
\hline B. Drug addict & - & - & - \\
\hline C. Blood transfusions & $2(4.0 \%)$ & $2(4.0 \%)$ & - \\
\hline \multicolumn{2}{|c|}{ Table 2: Distribution according to Risk exposure } \\
\hline
\end{tabular}

In males, $27(72.9 \%)$ had multiple heterosexual contact and $10(27.1 \%)$ had history of multiple heterosexual contact and had also visited a STD Clinic. Of the 11 females, 5 (45.5\%) of their spouses were HIV positive.

\begin{tabular}{|l|c|c|}
\hline \multicolumn{1}{|c|}{ Presenting Symptoms } & Number & $\%$ \\
\hline 1. Fever & 37 & 74.0 \\
\hline 2. Anorexia & 34 & 68.0 \\
\hline 3. Weight loss & 25 & 50.0 \\
\hline 4. Lethargy & 20 & 40.0 \\
\hline 5. Cough & 19 & 38.0 \\
\hline 6. Diarrhea & 17 & 34.0 \\
\hline 7. Malaise & 10 & 20.0 \\
\hline 8. Mouth ulcers & 9 & 18.0 \\
\hline 9. Lymphadenopathy & 7 & 14.0 \\
\hline 10. Breathlessness & 2 & 4.0 \\
\hline
\end{tabular}




\begin{tabular}{|l|l|l|}
\hline 11. Chest pain & 2 & 4.0 \\
\hline 12. Genital ulcers & 2 & 4.0 \\
\hline 13. Skin infection & 3 & 6.0 \\
\hline
\end{tabular}

Table 3: Distribution according to Presenting Symptoms

\begin{tabular}{|l|c|c|}
\hline \multicolumn{1}{|c|}{ Opportunistic Infection } & Number $(\mathrm{n}=50)$ & $\%$ \\
\hline A. Tuberculosis & 28 & 56.0 \\
\hline 1. Pulmonary & 13 & 46.4 \\
\hline 2. Extra pulmonary & 15 & 53.6 \\
\hline 3. Pulmonary + Extra Pulmonary & 4 & 14.3 \\
\hline B. Chronic Diarrhea & 17 & 34.0 \\
\hline C. Oropharyngeal Candidiasis & 9 & 18.0 \\
\hline D. Pneumonitis & 5 & 10.0 \\
\hline E. Skin infection & 2 & 4.0 \\
\hline F. Genital warts & 2 & 4.0 \\
\hline G. Pericardial Effusion & 1 & 2.0 \\
\hline H. Herpes Zoster & 1 & 2.0 \\
\hline I. Cryptococcal Meningitis & 2 & 4.0 \\
\hline J. Pelvic Inflammatory Disease & 1 & 2.0 \\
\hline Table 4: Distribution according to Opportunistic Infections \\
\hline
\end{tabular}

The common opportunistic infections in study group were Tuberculosis, Chronic diarrhea, Oropharyngeal candidiasis, Pneumonitis, Skin infection, Genital warts and Cryptococcal meningitis. Herpes zoster, Pelvic inflammatory disease and Pericardial effusion were other opportunistic infections seen in our study group

\begin{tabular}{|c|c|c|}
\hline CD4 counts & Number $(\mathrm{n}=50)$ & $\%$ \\
\hline$<100$ & 3 & 6.0 \\
\hline $101-200$ & 18 & 36.0 \\
\hline $201-350$ & 21 & 42.0 \\
\hline$>350$ & 8 & 16.0 \\
\hline
\end{tabular}

\section{Table 5: Distribution according to CD4 counts}

The CD 4 counts were grouped under four different headings. They are $<100$ cells $/ \mu \mathrm{l}, 101-200$ cells/ $\mu \mathrm{l}, 201-350$ cells $/ \mu \mathrm{l}$ and $>350$ cells $/ \mu \mathrm{l}$.

The lowest CD 4 count recorded was 83 cells/ $\mu$ in 2 patients who had Extra pulmonary tuberculosis. The highest CD 4 count recorded was 742 cells $/ \mu l$ and the patient was asymptomatic. 
ORIGINAL ARTICLE

\begin{tabular}{|c|c|c|c|c|c|c|}
\hline \multirow{2}{*}{$\begin{array}{c}\text { Study parameters } \\
\text { (Mean } \pm \text { SD) }\end{array}$} & $<100$ & $101-200$ & $201-350$ & $>350$ & \multirow{2}{*}{ Overall } & \multirow{2}{*}{ P value } \\
\cline { 2 - 6 } Total count & $\begin{array}{c}4833.33 \\
\pm 1484.36\end{array}$ & $\begin{array}{c}4883.33 \\
\pm 2070.10\end{array}$ & $\begin{array}{c}6103.81 \\
\pm 1814.14\end{array}$ & $\begin{array}{c}9225.00 \\
\pm 4251.64\end{array}$ & $\begin{array}{c}6087.60 \\
\pm 2787.01\end{array}$ & 0.001 \\
\hline Total Lymphocyte & 1780.67 & 1774.44 & 1799.48 & 2490.75 & 1889.94 & \\
count & \pm 385.52 & \pm 683.33 & \pm 455.93 & \pm 1082.33 & \pm 698.74 & 0.073 \\
\hline Hemoglobin & 9.86 & 11.55 & 12.10 & 11.69 & 11.70 & \multirow{2}{*}{0.219} \\
& \pm 1.15 & \pm 1.76 & \pm 1.60 & \pm 2.15 & \pm 1.76 & \\
\hline \multirow{2}{*}{ ESR } & 64.00 & 58.88 & 50.14 & 71.00 & 57.46 & \multirow{2}{*}{0.298} \\
& \pm 36.16 & \pm 26.59 & \pm 25.42 & \pm 29.01 & \pm 27.18 & \\
\hline
\end{tabular}

Table 6: Mean pattern of study parameters with CD4 counts

\begin{tabular}{|l|c|c|}
\hline \multicolumn{1}{|c|}{ Study parameters } & Pearson correlation & P value \\
\hline Total counts & 0.638 & $\mathrm{P}<0.001^{* *}$ \\
\hline Total Lymphocyte counts & 0.383 & $0.006^{* *}$ \\
\hline Hemoglobin & 0.240 & 0.093 \\
\hline \multicolumn{2}{|c|}{ Table 7: Pearson correlation of Study Parameters } \\
\hline
\end{tabular}

** Highly significant

The Pearson Correlation of Total Counts and Total Lymphocyte Counts with CD 4 Counts were highly significant and that of Hemoglobin was significant.

The Total Count showed an upward trend with CD 4 count. The Pearson Correlation between TC and CD 4 Counts was 0.638 , which is highly significant at $\mathrm{P}<0.001$ and shows a large correlation between the two variables.

In our study the Total Lymphocyte Count showed an upward trend with CD 4 count. The Pearson Correlation for TLC with CD 4 Counts was 0.383 (moderate correlation), which is highly significant at $\mathrm{P}<0.006$.

The Pearson Correlation for Hemoglobin with CD 4 Counts was 0.240 , at $\mathrm{P}<0.093$ and shows a small correlation between the two variables. ESR also showed an upward trend with CD 4 Count.

DISCUSSION: Between March 2004 and March 2006, 50 HIV patients admitted in KIMS Hospital or those patients who were examined and treated on an Outpatient basis in the Medical OPD constituted the study population. Of the 50 patients 41 were Inpatients and 9 were Outpatients because majority of the patients were symptomatic and were in the advanced stages of HIV infection. Spouses of HIV positive patients constituted the major chunk of the asymptomatic patients. 


\section{Age and Sex:}

\begin{tabular}{|c|c|c|c|c|}
\hline & Our study $\mathbf{n = 5 0}$ & $\begin{array}{c}\text { NAC0 } \\
\mathbf{n = 2 8 9 0}\end{array}$ & Kothari $\mathbf{n = 1 0 0}$ & A.R. Sircar $\mathbf{n = 2 7 8}$ \\
\hline $\begin{array}{c}\text { Male: female ratio } \\
\text { (31-50years) }\end{array}$ & $4: 1$ & $4: 1$ & $5: 1$ & $3: 1$ \\
\hline
\end{tabular}

Table 8: Comparison of Male: female ratio among different studies

In our study, the majority, 35 (70\%) patients were in the age group of 31-50 years, of which 28 were males and 7 were females. The Male to Female ratio was thus 4:1.

\section{Risk Factors:}

\begin{tabular}{|l|l|c|c|c|c|c|c|c|}
\hline A & $\begin{array}{c}\text { SEXUAL } \\
\text { TRANSMISSION }\end{array}$ & $\begin{array}{c}\text { Our Study n= } \\
\mathbf{5 0}\end{array}$ & $\begin{array}{c}\text { A.R. Sircar } \\
\mathbf{n = 2 7 8}\end{array}$ & $\begin{array}{c}\text { A.D. } \\
\text { Harris } \\
\mathbf{n = 1 5 0}\end{array}$ & $\begin{array}{c}\text { Kothari } \\
\mathbf{n = 1 0 0}\end{array}$ & $\begin{array}{c}\text { S.K. } \\
\text { Sharma } \\
\mathbf{n = 1 3 5}\end{array}$ & $\begin{array}{c}\text { ACP \& } \\
\text { IDSA n= 600 }\end{array}$ & $\begin{array}{c}\text { NACO- } \\
\mathbf{2 0 0 1} \\
\mathbf{n = 2 8 9 0}\end{array}$ \\
\hline 1. & Heterosexual & $31(64 \%)$ & $175(64 \%)$ & $93(62 \%)$ & $68(68 \%)$ & $81(60 \%)$ & $228(38 \%)$ & $1878(65 \%)$ \\
\hline 2. & $\begin{array}{l}\text { Heterosexual + } \\
\text { STD }\end{array}$ & $12(25 \%)$ & $27(10 \%)$ & $34(23 \%)$ & $27(27 \%)$ & $39(29 \%)$ & $84(14 \%)$ & $491(17 \%)$ \\
\hline 3. & $\begin{array}{l}\text { Homosexual + } \\
\text { STD }\end{array}$ & - & - & - & - & - & $120(20 \%)$ & $58(2 \%)$ \\
\hline 4. & $\begin{array}{l}\text { Spouse of HIV } \\
+\end{array}$ & $5(10 \%)$ & $25(9 \%)$ & $12(8 \%)$ & - & $13(7 \%)$ & $72(12 \%)$ & $173(6 \%)$ \\
\hline $\mathbf{5 .}$ & Bisexual & - & - & - & $2(2 \%)$ & - & $48(8 \%)$ & $29(1 \%)$ \\
\hline B. & Drug addicts & - & - & - & - & - & $42(7 \%)$ & $115(4 \%)$ \\
\hline C. & $\begin{array}{l}\text { Blood } \\
\text { transfusions }\end{array}$ & $2(4 \%)$ & $43(17 \%)$ & $10(7 \%)$ & $3(3 \%)$ & $5(4 \%)$ & $6(1 \%)$ & $144(5 \%)$ \\
\hline
\end{tabular}

Table 9: Comparison of modes of transmission of HIV in different studies

Heterosexual transmission was the commonest mode of spread of HIV infection in our study population which was similar to the findings in studies by A. R. Sircar et al (1998), A.D Harris (1990) and Kothari et al (2001). There were only 2 (4\%) patients who presented with a history of blood transfusion in our study, whereas $16.2 \%$ patients had history of blood transfusion in a study by A.R.Sircar et al (1998). IV

Presenting Symptoms:

\begin{tabular}{|l|c|c|c|c|c|c|}
\hline $\begin{array}{c}\text { Presenting } \\
\text { symptoms }\end{array}$ & $\begin{array}{c}\text { Our } \\
\text { study } \\
\text { n= 50 }\end{array}$ & $\begin{array}{c}\text { S.K } \\
\text { Sharma } \\
\text { study } \\
\mathbf{n = 1 3 5}\end{array}$ & $\begin{array}{c}\text { YRG } \\
\text { study } \\
\mathbf{n = 1 3 1 5}\end{array}$ & $\begin{array}{c}\text { ICMR bulletin } \\
\mathbf{n = 1 2 0 0}\end{array}$ & $\begin{array}{c}\text { A.R } \\
\text { Sirkar } \\
\mathbf{n = 2 7 8}\end{array}$ & $\begin{array}{c}\text { Kothari n= } \\
\mathbf{1 0 0}\end{array}$ \\
\hline Fever & $37(74 \%)$ & $95(71 \%)$ & $854(65 \%)$ & $336(42 \%)$ & $100(36 \%)$ & $46(46 \%)$ \\
\hline Anorexia & $34(68 \%)$ & $87(65 \%)$ & $394(30 \%)$ & $224(28 \%)$ & $97(35 \%)$ & $40(40 \%)$ \\
\hline Weight loss & $25(50 \%)$ & $37(28 \%)$ & $341(26 \%)$ & $544(68 \%)$ & $63(23 \%)$ & $22(22 \%)$ \\
\hline
\end{tabular}




\begin{tabular}{|l|r|r|r|r|r|r|}
\hline Diarrhea & $17(34 \%)$ & $33(25 \%)$ & $263(20 \%)$ & $276(21 \%)$ & $44(16 \%)$ & $33(33 \%)$ \\
\hline
\end{tabular}

Fevers, Anorexia, Weight loss, Lethargy, Cough, Diarrhea, Malaise, Mouth ulcers, Lymphadenopathy were the commonest clinical manifestations in our study population which were consistent with the findings in other studies.

Opportunistic infections:

\begin{tabular}{|l|c|c|c|c|c|}
\hline Opportunistic infections & $\begin{array}{c}\text { Our study } \\
\mathbf{n = 5 0}\end{array}$ & $\begin{array}{c}\text { S.K. } \\
\text { Sharma } \\
\mathbf{n = 1 3 5}\end{array}$ & $\begin{array}{c}\text { Beck } \\
\mathbf{n = 1 5 3 4}\end{array}$ & $\begin{array}{c}\text { Arthur } \\
\text { Pitchenik } \\
\mathbf{n = 3 0 6}\end{array}$ & $\begin{array}{c}\text { Sara } \\
\text { Chacko } \\
\mathbf{n = 8 5}\end{array}$ \\
\hline A. Tuberculosis & $56.0 \%$ & $71 \%$ & $53 \%$ & $56 \%$ & $52 \%$ \\
\hline B. Chronic Diarrhea & $34.0 \%$ & $26 \%$ & $24 \%$ & $37 \%$ & $28 \%$ \\
\hline C. Orophryngeal & $18.0 \%$ & $39 \%$ & $26 \%$ & $37 \%$ & $21 \%$ \\
\hline D. Pneumonitis & $10.0 \%$ & $7.4 \%$ & $22 \%$ & $26 \%$ & $12 \%$ \\
\hline E. Skin infection & $4.0 \%$ & $3 \%$ & $4 \%$ & $6 \%$ & $3 \%$ \\
\hline F. Genital warts & $4.0 \%$ & $1 \%$ & $11 \%$ & $8 \%$ & $5 \%$ \\
\hline G. Pericardial Effusion & $2.0 \%$ & $3 \%$ & $8 \%$ & $4 \%$ & - \\
\hline H. Herpes Zoster & $2.0 \%$ & $1 \%$ & $9 \%$ & $8 \%$ & $1 \%$ \\
\hline I. $\quad$ Cryptococcal & $4.0 \%$ & $3.7 \%$ & $15 \%$ & $13 \%$ & $8 \%$ \\
\hline J. $\quad \begin{array}{l}\text { Peningitis } \\
\quad \text { Disease }\end{array}$ & $2.0 \%$ & - & $4 \%$ & $3 \%$ & $1 \%$ \\
\hline K. Toxoplasmosis & - & $37 \%$ & $9 \%$ & $22 \%$ & - \\
\hline
\end{tabular}

Table 11: Comparison of opportunistic infections in different studies

Tuberculosis was the most common opportunistic infection present in our study population, present in 28 (56\%) patients. Contrary to the picture of AIDS in Africa and America our study as well as studies by A.R.Sircar et al (1998), Kothari et al (2001) and Sara Chacko et al (1994) have observed the absence of Kaposi's sarcoma, Toxoplasmosis, Lymphoma and Recurrent multidermatomal Herpes zoster.

\section{4 counts:}

\begin{tabular}{|c|c|c|c|c|}
\hline CD4 counts & $\begin{array}{c}\text { Our study } \\
(\mathbf{n = 5 0 )}\end{array}$ & Beck (n=153) & $\begin{array}{c}\text { John Hopkins study } \\
(\mathbf{n = 5 8 6 4 )}\end{array}$ & $\begin{array}{c}\text { YRG study } \\
\text { (n=1315) }\end{array}$ \\
\hline$<100$ & $3(6.0 \%)$ & $12(13 \%)$ & $1055(18 \%)$ & $105(8 \%)$ \\
\hline $101-200$ & $18(36.0 \%)$ & $53(34 \%)$ & $1584(27 \%)$ & $395(30 \%)$ \\
\hline $201-350$ & $21(42.0 \%)$ & $78(53 \%)$ & $3225(55 \%)$ & $905(62 \%)$ \\
\hline
\end{tabular}

Table 12: Comparison of distribution according to CD 4 counts in different studies 
The CD 4 counts were less than 200 cells/ $\mu$ in 20 (40\%) of the patients in our study.

The commonest opportunistic infections were Tuberculosis, Chronic Diarrhea and Oropharyngeal Candidiasis. There was a significant relationship between CD 4 count and the presence of TB as the CD 4 counts varied from less than 100 cells $/ \mu$ to greater than 500 cells $/ \mu \mathrm{l}$. As the CD 4 count declines, incidence of extrapulmonary Tuberculosis increases over Pulmonary Tuberculosis.

In our study, Total count and Total Lymphocyte Count were showing positive trend to CD 4 counts and are statistically significant. The Total Counts of 4850 cells/ $\mu$ l and 9200 cells/ $\mu$ l showed similar observations to CD 4 counts of 200 cells/ $\mu$ land 350 cells/ $\mu$ l. The Total Lymphocyte Counts of 1750 cells/ $\mu \mathrm{l}$ and 2450 cells/ $\mu \mathrm{l}$ showed similar observations to CD 4 counts of 200 cells/ $\mu \mathrm{l}$ and 350 cells/ $\mu$ l respectively. The $\mathrm{P}$ value was highly significant with Pearson Correlation of 0.638 for Total Counts (P value $<0.001$ ) and 0.383 for Total Lymphocyte Count (P value $<0.006)$. In the study done by Beck EJ et al at Academic Department of Public Health, St. Mary's Hospital Medical School, London, U.K. paired Total Lymphocyte Count and CD 4 counts were taken from 1534 patients. A significant correlation between the above two parameters was noted, especially for patients with symptomatic HIV disease. This demonstrates the suitability of the use of Total Lymphocyte Count in the absence of CD 4 count.

\begin{tabular}{|l|c|c|c|}
\hline \multicolumn{1}{|c|}{ Studies } & \multicolumn{2}{c|}{ Different indices } \\
\hline & TC & TLC & Hb \\
\hline Our study & 6087 & 1889 & 11.228 \\
\hline John Hopkins study & 5267 & 1196 & 10.874 \\
\hline YRG study & 5876 & 1252 & 11.160 \\
\hline Beck E.J study & 6028 & 1300 & 11.279 \\
\hline KMC study (Manipal) & 5276 & 1205 & 11.245 \\
\hline 'p' value & 0.001 & 0.074 & 0.219 \\
\hline Pearson Correlation & Highly significant & Highly significant & Significant \\
\hline \multicolumn{4}{|c|}{ TABLE 13: Comparison of conclusions of different studies with CD 4 of 200 cells/ $\mu \mathrm{l}}$. \\
\hline
\end{tabular}

The pattern of CD 4 counts over time is more important than any single CD 4 count value. CD 4 counts generally decrease as HIV progresses. Therefore it is more valuable to evaluate a series of CD 4 counts than any single CD 4 count.

As the CD 4 count is affected by the time of the day (lower in the morning), in acute illnesses, refrigeration of the blood sample (decreased CD 4 count), with rough handling or contamination of blood sample, so the serial recording of Total Lymphocyte Count can give an equally stable reflection of progression of disease and development of AIDS in HIV infected persons.

\section{CONCLUSIONS:}

(1) Majority of the patients with opportunistic infections had a CD 4 count less than 350 cells $/ \mu \mathrm{l}$.

(1) The Total Lymphocyte Counts of 1750 cells/ $\mu$ land 2450 cells/ $\mu$ l correlated to CD 4 counts of 200 cells $/ \mu \mathrm{l}$ and 350 cells/ $\mu$ l respectively. 
(A) The correlation between Total Lymphocyte Count and CD 4 count were highly significant.

(1) Thus, for the people who may not be able to afford the investigations and treatment, Total Lymphocyte Count can serve as a cost effective, affordable index to start ART and also to monitor ART in HIV infected persons.

\section{BIBLIOGRAPHY:}

1. Ministry Of health and Family Welfare. National AIDS Control Organisation. Combating HIV/AIDS in India 2001.

2. Joint United Nations Programme on HIV/AIDS (UNAIDS)/ World Health Organisation (WHO). AIDS epidemic update; December 2000. Geneva: UNAIDS/WHO, 2000. Publication UNAIDS/00. 44EWHO/CDS/CSR/EDC/2000.9.

3. NACO 2001; Estimation of HIV infection among adult population. Web: http.//naco.nic.in/vsnaco/update.htm

4. World Health Organisation. Scaling up antiretroviral therapy in resource-limited settings: Treatment Guidelines for a Public Health Approach. 2003 Revision. Geneva: World Health Organisation; 2003. Available at: http:/www.wgho.int/3by5/publications/documentary/arv_guidelines/en.

5. Stephenson J. Cheaper HIV drugs for poor nations bring a new challenge: monitoring treatment. JAMA. 2002; 288:151-153.

6. Kumaraswamy N, Flanigan TP, Mahajan AP et al. Monitoring HIV treatment in the developing world. Lancet Infect Dis. 2002; 2:656-657.

7. Joint National Programme on HIV/AIDS (UNAIDS) and the World Health Organisation. Guidance Modules on Antiretroviral Treatments. UNAIDS and the World Health Organisation; 1998. WHO/AASD/98.1 UNAIDS/97.7

8. Montaner JSG, Le TN, Le N et al. Application of the World Health Organisation System for HIV infection in a cohort of Homosexual men in developing a prognostically meaningful staging system. AIDS 1992; 6:719-724.

9. Post FA, Wood R, Maartens G. CD 4 and Total Lymphocyte Counts as predictors of HIV Disease Progression. QJMED. 1996; 89:505-508.

10. Blat SP, Luce CR, Butzin CA et al. Total Lymphocyte Count as a Predictor of Absolute CD 4 count and CD percentage in HIV infected persons. JAMA.1993; 269:622-626.

11. Beck EJ, Kupek EJ, Gompels MM et al. Correlation between Total and CD 4 Lymphocyte Counts in HIV infection: not making the good enemy of the not so perfect. Int J STD AIDS. 1996; 7:422428.

12. Kumaraswamy N, Mahajan AP, Flanigan TP et al. The Total Lymphocyte Count is a Useful tool for the Timing of Opportunistic infection Prophylaxis in India and other resource constrained countries. JAIDS 2002; 31:378-383.

13. Gange SJ, Lau B, Phair J et al. Rapid declines in total lymphocyte count and hemoglobin in HIV infection begin at CD 4 lymphocyte counts that justify antiretroviral therapy. AIDS 2003; 17:119-121.

14. Jacobson MA, Liu L, Khayam-Bashi $\mathrm{H}$ et al. Absolute or total lymphocyte count as marker for the CD 4 T lymphocyte criterion for initiating antiretroviral therapy. AIDS. 2003; 17:917-919. 


\section{ORIGINAL ARTICLE}

15. Spacek LA, Griswold M, Quinn TC et al. Total Lymphocyte Count and hemoglobin combined in an algorithm to initiate the use of highly active antiretroviral therapy in resource-limited settings. AIDS. 2003; 17:1311-1317.

16. HIV testing Manual. National institute of communicable diseases. Ministry of Health and Family Welfare. National AIDS control Organisation.

\section{KEY TO MASTER CHART}

$\mathrm{A} \quad=$ Anorexia

$\mathrm{ALB}=$ Albumin

ABD.KOCH $=$ Abdominal Koch

$\mathrm{B}=$ Breathlessness

BL.KOCH = Bilateral Koch's

BRONCHI. $=$ Bronchitis

$\mathrm{C}=$ Cough

$\mathrm{C} / \mathrm{S}=$ Culture and Sensitivity

$\mathrm{CP}=$ Chest Pain

CSF $=$ Cerebro-spinal Fluid

$\mathrm{D}=$ Diarrhoea

$\mathrm{F} \quad=$ Fever

GU = Genital Ulcers

KLEB = Klebsiella

L = Lymphadenopathy

LTH = Lethargy

$\mathrm{M}=$ Malaise

MENG = Meningitis

MU = Mouth Ulcers

$\mathrm{N}=$ Normal

$\mathrm{NG}=$ No Growth

$\mathrm{PC}=$ Pus Cells

PER.EFU $=$ Pericardial Effusion PLEU.EFU $=$ Pleural effusion

PL.THICK = Pleural Thickening

PNEUM = Pneumonia

P.RUB = Pleural Rub

PUL.KOCH = Pulmonary Koch

RT.EFU $=$ Right sided Pleural effusion

TB.LYMPH = Tubercular Lymphadenitis

$\mathrm{WL}=$ Weight Loss

$+=$ Positive

- = Negative 


\section{ORIGINAL ARTICLE}

\section{AUTHORS:}

1. Keshava H.K.

2. Manjunath R.

\section{PARTICULARS OF CONTRIBUTORS:}

1. Assistant Professor, Department of General Medicine, Kempegowda Institute of Medical Sciences, Bangalore.

2. Professor, Department of General Medicine, Kempegowda Institute of Medical Sciences, Bangalore.

\section{NAME ADDRESS EMAIL ID OF THE CORRESPONDING AUTHOR:}

Dr. Keshava H.K, Assistant Professor, Department of General Medicine, Kempegowda Institute of Medical Sciences, K.R. Road, V.V. Puram, Bangalore - 40.

E-mail: drkeshavahk@gmail.com

Date of Submission: 13/01/2014. Date of Peer Review: 14/01/2014. Date of Acceptance: 22/01/2014. Date of Publishing: 31/01/2014. 